\title{
Effects of $\beta$-adrenergic stimulation on the ventricular action potential: a simulation study
}

\author{
E. Grandi, S. Vecchietti, S. Severi, E. Giordano \& S. Cavalcanti \\ Cellular and Molecular Engineering Laboratory, \\ University of Bologna, Italy
}

\begin{abstract}
Cathecholamines increase heart rate and contraction force. This effect is mainly mediated by their interaction with the $\beta$-adrenergic receptor ( $\beta$-AR) and its downstream ability to modulate $\mathrm{Ca}^{2+}$ cycling and fluxes of a number of ions through specific channels across the cell membrane. The complex nature and broad cellular influence of the $\beta$-AR signaling cascade suggests that an integrative modelling approach is appropriate to size the relative weight of each of the single mechanisms by which $\beta$-adrenergic inputs modulate whole-cell action potential (AP) and $\mathrm{Ca}^{2+}$ handling in cardiac myocytes. The ventricular AP was simulated by using the Luo-Rudy model. The transmural heterogeneity of the AP (epicardial, mid-myocardial and endocardial cells) was reproduced by considering three different levels of expression of the transient outward current $\left(\mathrm{I}_{\mathrm{To}}\right)$ and three different ratios of the slow vs. the rapid component of the delayed rectifier $\mathrm{K}^{+}$current $\left(\mathrm{I}_{\mathrm{Ks}} / \mathrm{I}_{\mathrm{Kr}}\right)$. The $\beta$-AR stimulation was modelled by incorporating its effects on L-type $\mathrm{Ca}^{2+}$ current, phospholamban, $\mathrm{I}_{\mathrm{Kr}}, \mathrm{I}_{\mathrm{Ks}}, \mathrm{Na}^{+}-\mathrm{K}^{+}$ pump and $\mathrm{Na}^{+} / \mathrm{Ca}^{2+}$ exchanger. Simulation of $\beta$-AR stimulation showed significant changes in the $\mathrm{AP}$ and in $\mathrm{Ca}^{2+}$ handling, depending on the cell type and on the levels of ion fluxes alterations due to $\beta$-adrenergic inputs. Notably, the occurrence of early- and delayed-after-depolarizations (EADs and DADs respectively) was also reproduced. In the present analysis, EADs and DADs are suggested as mechanisms responsible for the arrhythmogenic effect of the adrenergic stimulation.
\end{abstract}

Keywords: $\beta$-adrenergic stimulation, computer modelling, arrhythmia. 


\section{Introduction}

The sympathetic neurotransmitter norepinephrine and the adrenal hormone epinephrine (both referred to as cathecholamines) increase the force of contraction and the rate of relaxation of cardiac muscle. These actions are initiated by $\beta$-adrenergic receptor ( $\beta$-AR) coupling with the stimulatory Gprotein and subsequent stimulation of adenylyl cyclase, which synthesizes the classical second messenger cyclic AMP (cAMP). cAMP activates cAMPdependent protein kinase (PKA), leading to the phosphorylation of a wide spectrum of target proteins directly involved in excitation - contraction (EC) coupling.

\subsection{L-type $\mathrm{Ca}^{2+}$ channel}

Upon depolarization, $\mathrm{Ca}^{2+}$ flowing into the cell through the L-type calcium channels leads to $\mathrm{Ca}^{2+}$ release from the sarcoplasmic reticulum (SR). This influx of $\mathrm{Ca}^{2+}$ during subsequent beats also loads the SR and participates in activation of myofilaments. Thus, controlling the amount of $\mathrm{Ca}^{2+}$ influx through the cell membrane the L-type calcium current $\left(\mathrm{I}_{\mathrm{Ca}(\mathrm{L})}\right)$ is a key determinant of contractility.

$\beta$-adrenergic agents such as isoproterenol have been shown to enhance $\mathrm{I}_{\mathrm{Ca}(\mathrm{L})}$, through the PKA-induced phosphorylation of the channel [1].

\subsection{Phospholamban}

Phospholamban (PLB) is the main regulator the $\mathrm{Ca}^{2+}$-ATPase activity in cardiac SR. $\beta$-adrenergic stimulation increases the phosphorylation of this regulatory protein [2], causing phospholamban to dissociate from the SR $\mathrm{Ca}^{2+}$-ATPase, thus increasing the rate of $\mathrm{Ca}^{2+}$ uptake $\left(\mathrm{I}_{\text {up }}\right)$ into the SR.

\subsection{Delayed-rectifier slowly activated $\mathrm{K}^{+}$current}

The slow component of the delayed-rectifier $\mathrm{K}^{+}$current $\left(\mathrm{I}_{\mathrm{Ks}}\right)$ plays an important role during the repolarization in the human heart. The $\beta$-AR agonist isoproterenol has been shown to increase 2- to 3-fold the current magnitude of $\mathrm{I}_{\mathrm{Ks}}[3]$.

\subsection{Delayed-rectifier rapidly activated $\mathrm{K}^{+}$current}

Another critical repolarizing $\mathrm{K}^{+}$current is the rapid component of the delayedrectifier $\mathrm{K}^{+}$current $\left(\mathrm{I}_{\mathrm{Kr}}\right)$. It has recently been demonstrated that $\mathrm{I}_{\mathrm{Kr}}$ is regulated by $\beta$-adrenoreceptor stimulation via a PKA dependent pathway [4]. $\mathrm{I}_{\mathrm{Kr}}$ is reduced by PKA activation.

\section{$1.5 \mathrm{Na}^{+}-\mathrm{K}^{+}$pump}

Ion transport mediated by the $\mathrm{Na}^{+}-\mathrm{K}^{+}$pump has been suggested to be stimulated by either norepinephrine or isoproterenol. This increase in the $\mathrm{Na}^{+}-\mathrm{K}^{+}$current $\left(\mathrm{I}_{\mathrm{NaK}}\right)$ has been shown to be mediated by $\beta$-AR activation [5]. 


\section{$1.6 \mathrm{Na}^{+} / \mathrm{Ca}^{2+}$ exchanger}

The $\mathrm{Na}^{+} / \mathrm{Ca}^{2+}$ exchanger protein is a key element in intracellular $\mathrm{Ca}^{2+}$ regulation in many cell types. It has been reported that the current generated by the $\mathrm{Na}^{+} / \mathrm{Ca}^{2+}$ exchange process $\left(\mathrm{I}_{\mathrm{NaCa}}\right)$ is increased by activation of the $\beta$-AR/PKA pathway [6].

Sympathetic stimulation modulates physiological cardiac activity, but also is involved in many pathophysiological conditions. Notably, life-threatening arrhythmias can be triggered by sympathetic activation. However, the outcome of $\beta$-AR activity is the result of coordinated modulation of several ionic fluxes, so that it may result difficult to size their relative importance. In the present study, a mathematical model of ventricular AP was used to investigate the effects of the $\beta$-adrenergic inputs on the cardiac electrical activity and contractility at the cellular level. In particular, different levels of alteration of $\mathrm{I}_{\mathrm{Ca}(\mathrm{L})}$ and $\mathrm{I}_{\text {up }}$ were analysed.

\section{Methods}

The ventricular AP was simulated by using the Luo-Rudy (LRd) model (Fig. 1) [7] implemented in Simulink 5 (The MathWorks. Inc- Natick, Mass; USA).

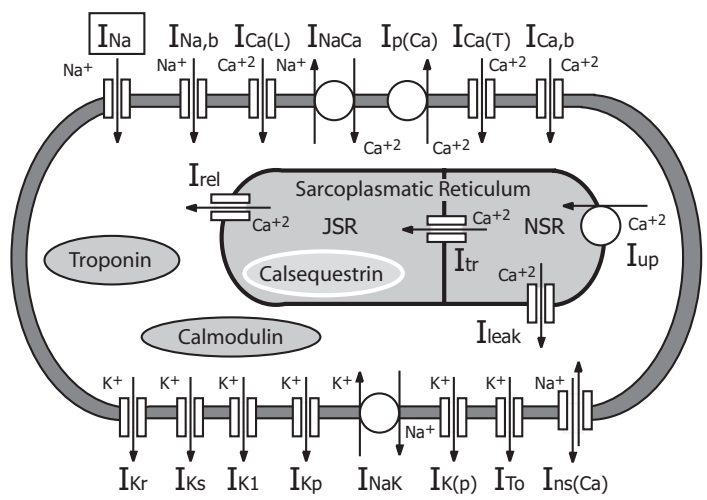

Figure 1: Schematic diagram of the Luo-Rudy ventricular cell model.

This model is mostly based on guinea pig experimental data, including parameters describing membrane ionic currents, ion pumps and exchangers. In this study, the Hodgkin-Huxley formulation of $\mathrm{I}_{\mathrm{Na}}$ was substituted with a more detailed Markov model [8], and the transient outward current $\mathrm{I}_{\text {To }}$ described by Dumaine et al. [9] was added. Simulations were performed considering individually the epicardial (Epi), midmyocardial (M) and endocardial (Endo) cells, differentially simulated by assigning three distinct expression levels of maximal conductance of the transient outward current $\left(\mathrm{G}_{\mathrm{To}}\right)$ [9] and three ratios of slow $\left(\mathrm{I}_{\mathrm{Ks}}\right)$ vs. rapid $\left(\mathrm{I}_{\mathrm{Kr}}\right)$ components of the delayed-rectifier potassium current 
[10]. In Epi cells $\mathrm{G}_{\mathrm{To}}$ was set to $1100 \mathrm{~S} / \mathrm{F}$ and the density ratio of $\mathrm{I}_{\mathrm{Ks}}$ to $\mathrm{I}_{\mathrm{Kr}}$ was set to 63. In $M$ cells, $\mathrm{G}_{\mathrm{To}}=500 \mathrm{~S} / \mathrm{F}$ and $\mathrm{I}_{\mathrm{Ks}} / \mathrm{I}_{\mathrm{Kr}}=23.3$. In Endo cells, $\mathrm{G}_{\mathrm{To}}=50$ $\mathrm{S} / \mathrm{F}$ and $\mathrm{I}_{\mathrm{Ks}} / \mathrm{I}_{\mathrm{Kr}}=29.6$. Maximal conductance of L-Type calcium current was decreased by $20 \%$ with respect to the original LRd formulation in all cells [9].

$\beta$-AR stimulation was modelled by incorporating PKA-mediated effects on L-type $\mathrm{Ca}^{2+}$ channels, PLB, $\mathrm{I}_{\mathrm{Kr}}, \mathrm{I}_{\mathrm{Ks}}, \mathrm{Na}^{+}-\mathrm{K}^{+}$pump and $\mathrm{Na}^{+} / \mathrm{Ca}^{2+}$ exchanger. Two different profiles of alteration of ion fluxes were simulated (Table 1).

Table 1: $\quad$ Simulated alterations of ion currents due to $\beta$-AR stimulation. Values are the percentage of the baseline current. In parenthesis the bibliographic references are indicated.

\begin{tabular}{ccc}
\hline Current & Case 1 & Case 2 \\
\hline $\mathrm{I}_{\mathrm{Ca}(\mathrm{L})}$ & $250^{[1]}$ & $200^{[1]}$ \\
$\mathrm{I}_{\mathrm{up}}$ & $140^{[2]}$ & $300^{[2]}$ \\
$\mathrm{I}_{\mathrm{Kr}}$ & $30^{[4]}$ \\
$\mathrm{I}_{\mathrm{Ks}}$ & $250^{[3]}$ \\
$\mathrm{I}_{\mathrm{NaK}}$ & $120^{[5]}$ \\
$\mathrm{I}_{\mathrm{NaCa}}$ & $140^{[6]}$ \\
\hline
\end{tabular}

Pacing was obtained by a current pulse train (pulses of $1 \mathrm{~ms}$ in duration) of $50 \mathrm{~A} / \mathrm{F}$ in amplitude with frequency of $80 \mathrm{bpm}$. Rosenbrock variable step algorithm (max step $0.1 \mathrm{~ms}$ ) was used to numerically solve the model equations. In order to ensure a steady state condition, $180 \mathrm{~s}$ long simulations were performed.

\section{Results}

When the case 1 is simulated, the response of cardiac cell to $\beta$-AR stimulation is related to the myocardial layer where the cell belongs. In fact, AP shape and duration of Endo and Epi cells were not modified by the sympathetic stimulation (Fig.2, left lane, upper and lower panels), while $\mathrm{M}$ cell was dramatically influenced. Notably, the repolarization of the cell in this layer was retarded and early-after-depolarizations (EADs) occurred (Fig.2, left lane, middle panel). In our simulations these latter are mainly due to the reactivation of the depolarizing current $\mathrm{I}_{\mathrm{Ca}(\mathrm{L})}$ (not shown), determining a net inward current in the plateau phase. At the same time, the enhanced $\mathrm{Ca}^{2+}$ uptake and the increased $\mathrm{I}_{\mathrm{Ca}(\mathrm{L})}$ concentrate $\mathrm{Ca}^{2+}$ into the SR and hence enlarge the size of the $\mathrm{Ca}^{2+}$ transient observed during $\beta$-adrenergic stimulation in all cell types (Fig.2, right lane).

Also when a further increase in the rate of $\mathrm{Ca}^{2+}$ uptake into the SR was simulated (case 2), M cells showed a prolonged AP with respect to control condition, whereas Epi end Endo cells showed only slight changes (Fig.3, left lane). Notably, in all cell types delayed-after-depolarizations (DADs) arose after 
full repolarization (Fig.3, left lane). DADs are linked to spontaneous $\mathrm{Ca}^{2+}$ releases from the SR due to $\mathrm{Ca}^{2+}$ overload in this compartment, which in turn reflects the enhanced rate of $\mathrm{Ca}^{2+}$ uptake. In our simulations, the late increase in the intracellular $\mathrm{Ca}^{2+}$ concentration (Fig.3, right panel) induces a large inward current carried by the $\mathrm{Na}^{+} / \mathrm{Ca}^{2+}$ exchanger (not shown). This late depolarizing current is responsible for the observed oscillations of the membrane potential.
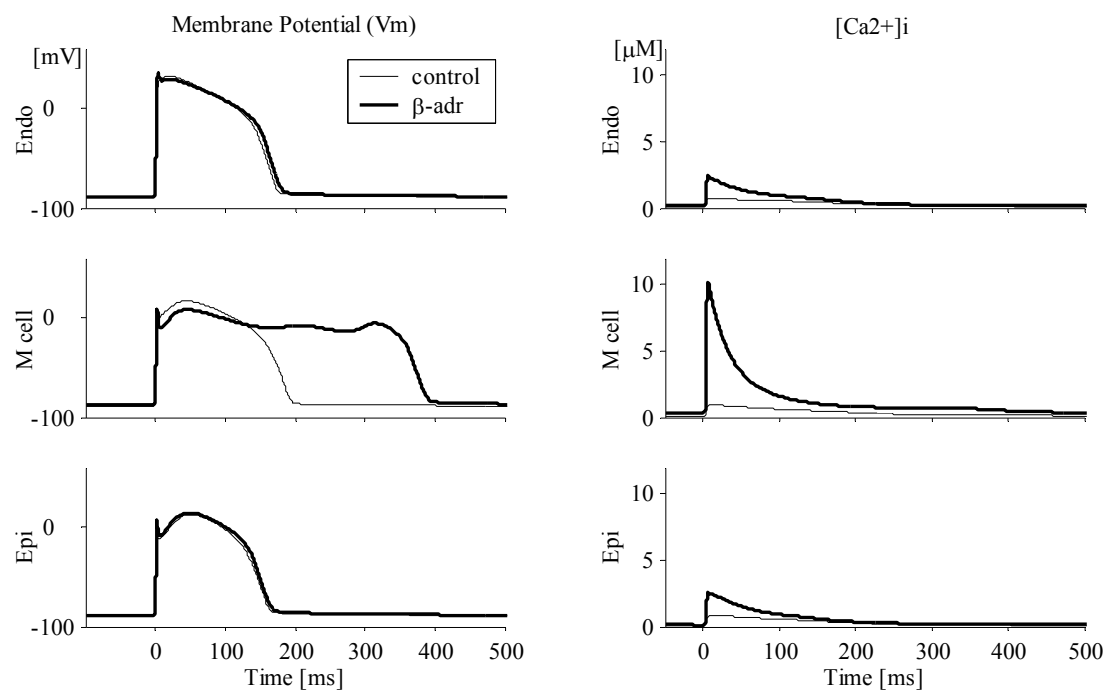

Figure 2: Simulated APs (left lane) and $\mathrm{Ca}^{2+}$ transients (right lane) corresponding to condition 1 .

\section{Discussion}

Although adrenergic stimulation has been described as the responsible for the development of cardiac arrhythmias in many pathological conditions, such as the Long QT (LQT) Syndrome and cardiac ischemia, the cellular basis for the arrhythmogenic actions of the sympathetic nervous system is poorly understood. $\beta$-adrenergic control of cardiac contractility is believed to be dominated by PKA phosphorylation of the L-type $\mathrm{Ca}^{2+}$ channel and PLB, important players in the regulation of $\mathrm{Ca}^{2+}$ dynamics and transport. In the present study, a mathematical model of ventricular AP was used to analyse the role of PKA phopshorylation of L-type $\mathrm{Ca}^{2+}$ channels and PLB in modulating the whole-cell response to $\beta$ adrenergic inputs in different ventricular layers.

Action Potential. The response of AP to $\beta$-adrenergic stimulation largely depends on the balance between the inward and outward currents active during the plateau phase. In our simulations this balance is shifted according to the cell type. In Endo and Epi cells, an increase in the outward repolarizing current, due 
to a relatively large increase of $\mathrm{I}_{\mathrm{Ks}}$, vs. an increase in the inward depolarizing current, $\mathrm{I}_{\mathrm{Ca}(\mathrm{L})}$, makes the AP insensitive to $\beta$-adrenergic stimulation (Fig. 2, left lane, upper and lower panels), whereas the prolonging of the M cell AP (Fig. 2, left lane, middle panel) reflects the shift of the balance in favour of $\mathrm{I}_{\mathrm{Ca}(\mathrm{L})}$. In detail, if $\mathrm{I}_{\mathrm{Ca}(\mathrm{L})}$ is sufficiently enhanced, the prolonged AP is accompanied by induction of EADs. These results are consistent with experimental data by Burashnikov and Antzelevitch [11], who showed that isoproterenol (in the presence of $\mathrm{I}_{\mathrm{Ks}}$ blockade) significantly prolonged the AP of M, and caused little change in Epi and Endo cells. However, the study did not show induction of EADs by isoproterenol. In fact, the $\mathrm{M}$ cell has been reported to have an intrinsically smaller $\mathrm{I}_{\mathrm{Ks}}$ among the three transmural cell types [10]. In general, a defect in $\mathrm{I}_{\mathrm{Ks}}$ (e.g. LQT Syndrome) could offset the balance between depolarizing and repolarizing currents, thus creating the bases for cardiac arrhythmias to develop. In the LQT1 model (reduced $\mathrm{I}_{\mathrm{Ks}}$ ), Shimizu and Antzelevitch showed that isoproterenol prolongs the AP of the $\mathrm{M}$ cell because of $\mathrm{I}_{\mathrm{Ks}}$ (outward current) reduction to levels at which $\mathrm{I}_{\mathrm{Ca}(\mathrm{L})}$ (inward current) predominates. On the other hand, higher levels of $\mathrm{I}_{\mathrm{Ks}}$ in Epi and Endo cells (even in the presence of the $\mathrm{I}_{\mathrm{Ks}}$ blocker chromanol 293B) account for the reduced duration of their AP as a response to the $\beta$-agonist [12].
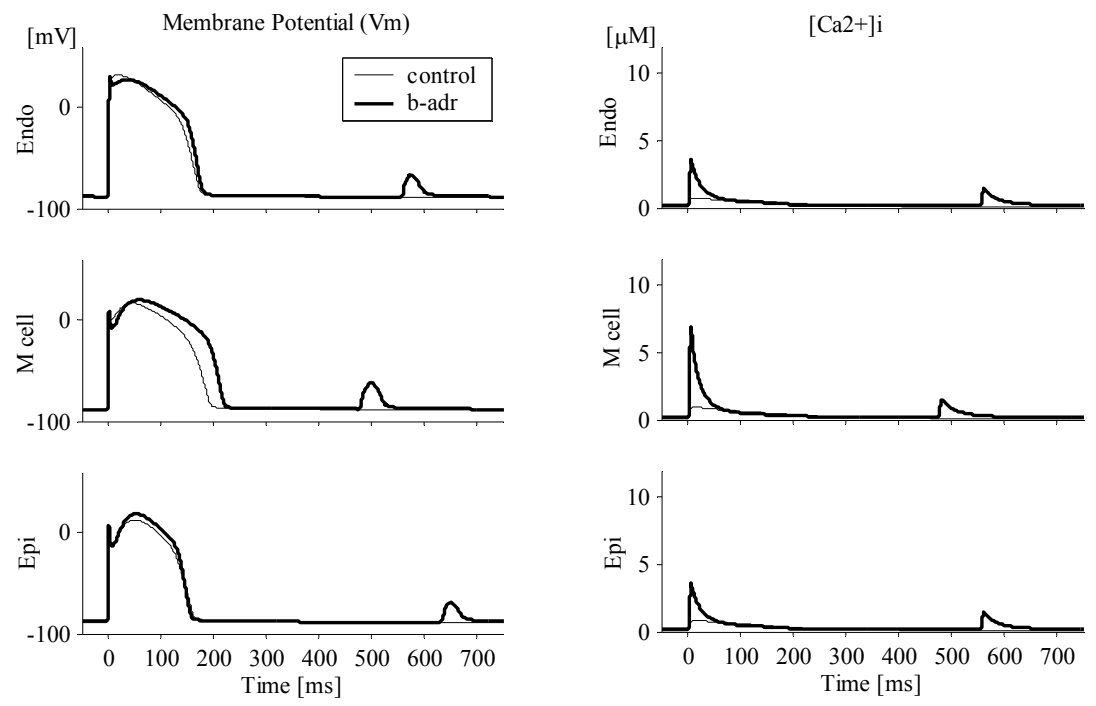

Figure 3: Simulated APs (left lane) and $\mathrm{Ca}^{2+}$ transients (right lane) corresponding to condition 2 .

When the $\mathrm{I}_{\text {up }}$ activity was further increased (condition 2), DADs occurred in all cell types (Fig.3, left panel). The induction of DADs by isoproterenol has been reported by Song et al. [1] and Burashnikov and Antzelevitch [11]. These oscillations of the membrane potential are caused by a transient outward current $\left(\mathrm{I}_{\mathrm{Ti}}\right)$, which is active in the late phase of the cardiac cycle. In our simulations, this 
current results to be carried by the $\mathrm{Na}^{+} / \mathrm{Ca}^{2+}$ exchanger (not shown), as it has already been shown by Zeng and Rudy [13].

Our results suggest an explanation for the role of sympathetic activity as a trigger for cardiac arrhythmias. In fact, when EADs and DADs are sufficiently large to depolarize the cell membrane to its voltage threshold, they give rise to triggered action potentials, which are believed to underlie some forms of extrasystolic activity and tachyarrhythmias.

$\mathrm{Ca}^{2+}$ handling. In all cell types, the simulation of sympathetic stimulation is accompanied by a large increase in the intracellular $\mathrm{Ca}^{2+}$ concentration (Figs. 23 , right lane), accounting for the well known inotropic response to $\beta$-adrenergic inputs. The observed changes depend on the increase in $\mathrm{Ca}^{2+}$ content in the SR, which in turn is due to the augmented rate of $\mathrm{Ca}^{2+}$ uptake by the SR and the increased size of $\mathrm{I}_{\mathrm{Ca}(\mathrm{L})}$. In addition, when the rate of $\mathrm{Ca}^{2+}$ uptake is further enhanced, oscillatory release of $\mathrm{Ca}^{2+}$ from the SR was also observed (Fig. 3, right lane), in agreement with Song et al. [1]. From the mechanical point of view, this spontaneous release, due to $\mathrm{Ca}^{2+}$ overload in the $\mathrm{SR}$, is associated with aftercontractions.

\section{Conclusions}

In the present analysis, the effects of $\beta$-stimulation on ventricular $\mathrm{AP}$ and $\mathrm{Ca}^{2+}$ cycling were investigated by using a computational model of the cardiac electrical activity. Depending on the levels of expression of $\mathrm{I}_{\mathrm{Ca}(\mathrm{L})}$ and $\mathrm{I}_{\mathrm{up}}$, EADs and DADs were suggested as mechanisms responsible for the arrhythmogenic effect of $\beta$-adrenergic stimulation. In addition, it is proposed that the increase in these fluxes also accounts for the elevated intracellular $\mathrm{Ca}^{2+}$ responsible for the augmented cardiac contractility.

\section{References}

[1] Song Y., Shryock J.C., Knot H.J., Belardinelli L., Selective attenuation by adenosine of arrhythmogenic action of isoproterenol on ventricular myocytes Am J Physiol Heart Circ Physiol, 281, pp. H2789-H2795, 2001

[2] Simmerman H.K.B., Jones L.R., Phospholamban: Protein Structure, Mechanism of Action, and Role in Cardiac Function. Physiol Rev, 78(4), 1998

[3] Kathofer S., Zhang W., Karle C., Thomas D., Schoels W., Kiehn J., Functional Coupling of Human b3-Adrenoreceptors to the KvLQT1/MinK Potassium Channel. J Biol Chem, 275(35), pp. 26743-26747, 2000

[4] Karle C.A., Zitron E., Zhang W., Kathofer S., Schoels W., Kiehn J., Rapid component $\mathrm{I}(\mathrm{Kr})$ of the guinea-pig cardiac delayed rectifier $\mathrm{K}(+)$ current is inhibited by beta(1)-adrenoreceptor activation, via cAMP/protein kinase A-dependent pathways. Cardiovasc Res., 53(2), pp.355-62, 2002

[5] Stimers J.R., Dobretsov M., Adrenergic stimulation of $\mathrm{Na} / \mathrm{K}$ pump current in adult rat cardiac myocytes in short-term culture. J Membr Biol., 163(3), pp.205-16, 1998 
[6] Pabbathi V.K., Zhang Y.H., Mitcheson J.S., Hinde A.K., Perchenet L., Arberry L.A., Levi A.J., Hancox J.C., Comparison of $\mathrm{Na}(+) / \mathrm{Ca}(2+)$ exchanger current and of its response to isoproterenol between acutely isolated and short-term cultured adult ventricular myocytes. Biochem Biophys Res Commun., 297(2), pp.302-8, 2002

[7] Faber G.M., Rudy Y., Action potential and contractility changes in $[\mathrm{Na}(+)](\mathrm{i})$ overloaded cardiac myocytes: a simulation study. Biophys $J, \mathbf{7 8}$ pp.2392-2404, 2000

[8] Vecchietti S., Rivolta I., Severi S., Napolitano C., Priori S.G., Cavalcanti S., Computer Simulation of the $\mathrm{Na}+$ Current in Wild-Type and Mutant Human Na+ Cardiac Channels. Submitted to Med Bio Eng Comput.

[9] Dumaine R., Towbin J.A., Brugada P., Vatta M., Nesterenko D.V., Nesterenko V.V., Brugada J., Brugada R., Antzelevitch C., Ionic mechanisms responsible for the electrocardiographic phenotype of the Brugada syndrome are temperature dependent. Circ Res, 85, pp.803-809, 1999

[10] Liu D.W., Antzelevitch C., Characteristics of the delayed rectifier current (IKr and IKs) in canine ventricular epicardial, midmyocardial, and endocardial myocytes. A weaker IKs contributes to the longer action potential of the M cell. Circ Res, 76, pp. 351-365, 1995

[11] Burashnikov A., Antzelevitch C., Block of I(Ks) does not induce early afterdepolarization activity but promotes beta-adrenergic agonist-induced delayed afterdepolarization activity. J Cardiovasc Electrophysiol., 11(4), pp.458-65, 2000

[12] Shimizu W, Antzelevitch C., Differential effects of beta-adrenergic agonists and antagonists in LQT1, LQT2 and LQT3 models of the long QT syndrome. J Am Coll Cardiol., 35(3), pp. 778-86, 2000

[13] Zeng J., Rudy Y., Early afterdepolarizations in cardiac myocytes: mechanism and rate dependence. Biophys J., 68(3), pp. 949-64, 1995 